\title{
Basin inversion: Reactivated rift structures in the Ligurian Sea revealed by OBS
}

Martin Thorwart ${ }^{1}$, Anke Dannowski ${ }^{2}$, Ingo Grevemeyer ${ }^{2}$, Dietrich Lange ${ }^{2}$, Heidrun Kopp ${ }^{1,2}$, Florian Petersen $^{2}$, Wayne Crawford ${ }^{3}$, Anne Paul ${ }^{4}$ and the AlpArray Working Group ${ }^{5}$

$5 \quad{ }^{1}$ CAU, Institute of Geosciences, Christian-Albrechts-Universität zu Kiel, 24105 Kiel, Germany

${ }^{2}$ GEOMAR, Marine Geodynamics, Helmholtz Centre for Ocean Research Kiel, 24148 Kiel, Germany

${ }^{3}$ IPGP, Laboratoire de Géosciences Marines, Institut de Physique du Globe de Paris, Paris, 75238 Cedex 5, France

${ }^{4}$ Univ. Grenoble Alpes, Univ. Savoie Mont Blanc, CNRS, IRD, UGE, ISTerre, 38000 Grenoble, France

${ }^{5}$ For the complete team list visit the link which appears at the end of the paper.

Correspondence to: Anke Dannowski (adannowski@geomar.de) or Martin Thorwart (martin.thorwart@ifg.uni-kiel.de)

\begin{abstract}
The northern margin of the Ligurian Basin shows notable seismicity at the Alpine front, including frequent magnitude 4 events. Seismicity decreases offshore towards the Basin centre and Corsica, revealing a diffuse distribution of low magnitude earthquakes. We analyse data of the amphibious AlpArray seismic network with focus on the offshore component, the AlpArray OBS network, consisting of 24 broadband ocean bottom seismometers deployed for eight months, to reveal the seismicity and depth distribution of micro-earthquakes beneath the Ligurian Sea.

Two clusters occurred between $\sim 10 \mathrm{~km}$ to $\sim 16 \mathrm{~km}$ depth below sea surface, within the lower crust and uppermost mantle. Thrust faulting focal mechanisms indicate compression and an inversion of the Ligurian Basin, which is an abandoned Oligocene rift basin. The Basin inversion is suggested to be related to the Africa-Europe plate convergence. The locations and

20 focal mechanisms of seismicity suggest reactivation of pre-existing rift structures. Slightly different striking directions of faults in the basin centre compared to faults further east and hence away from the abandoned rift may mimic the counter-clockwise rotation of the Corsica-Sardinia block during 20-16 Ma. The observed cluster events support the hypothesis of strengthening of crust and uppermost mantle during rifting related extension and thinning of continental crust.
\end{abstract}

\section{Introduction}

25 Earthquakes of magnitude 4 are frequently recorded in the Ligurian Basin, especially at the Ligurian margin at the junction between the southwestern Alps and the Ligurian Basin (hereafter named the Alps-Liguria junction) with maximum magnitudes of Mw 6 to 6.5, indicating a moderate seismic activity (Béthoux, 1992; Courboulex et al., 2007; Béthoux et al., 2008; Larroque et al., 2012, 2016). Seismic activity is highest along the Côte d'Azur and the Ligurian coast and decreases towards the central basin and Corsica (Fig. 1). The Ligurian Sea formed during Oligo-Miocene times as a back-arc basin (Burrus, 1984; Rehault et al., 1984; Faccenna et al., 1997; Gueguen et al., 1998; Rosenbaum et al., 2002), but extension stopped $\sim 16$ Ma. Today, GPS 
https://doi.org/10.5194/se-2021-9

Preprint. Discussion started: 5 February 2021

(C) Author(s) 2021. CC BY 4.0 License.

data do not show any significant shortening between Corsica and the northern rim of the Ligurian Sea (Nocquet and Calais, 2004), but compressive earthquakes occasionally occur. The interior of plates is, in general, predominantly aseismic (McKenzie and Parker, 1967). In these relatively stable tectonic regions, sparse seismicity may represent diffuse deformation and is commonly related to the reactivation of pre-existing fault planes (Zoback, 1992). In the Tyrrhenian Sea, the Africa-

35 Europe convergence caused reactivation of pre-existing fault planes, revealing an inversion of the entire basin (Zitellini et al., 2020).

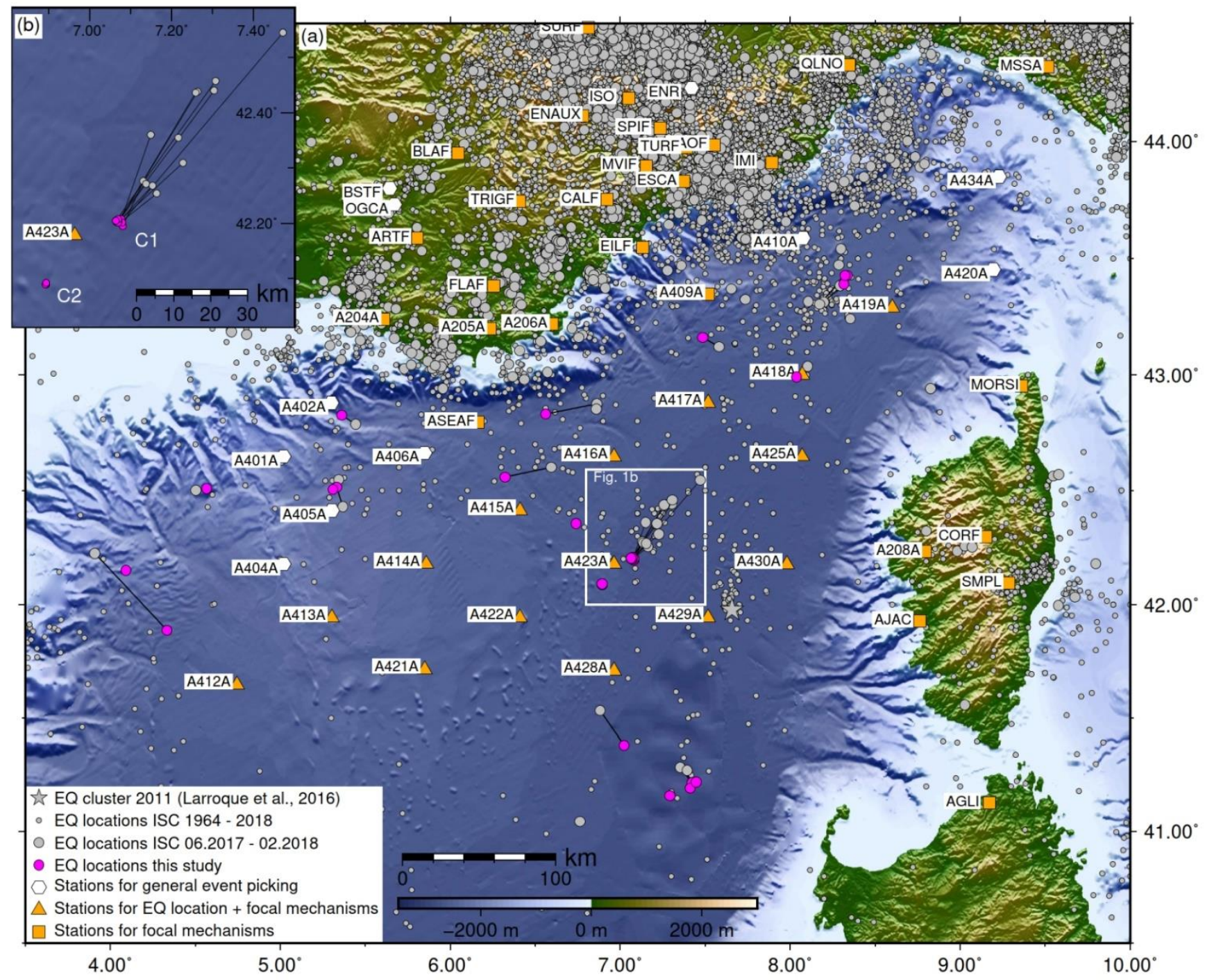

Figure 1: Topographic map of (a) the Ligurian Sea and (b) the area where the cluster events occur (GMRT data, Ryan et al., 2009). Grey circles mark the epicentres of earthquakes as observed in the ISC bulletin (Storchak et al., 2017). Magenta circles mark the 40 epicentres of earthquakes within the Ligurian Basin observed in this study. Black lines connect locations of the same events found in both the ISC bulletin and this study. 
https://doi.org/10.5194/se-2021-9

Preprint. Discussion started: 5 February 2021

(c) Author(s) 2021. CC BY 4.0 License.

(c) (i)

Here, we report on local seismicity in the centre of the Ligurian Basin (Fig. 1a). We analysed two earthquake clusters (Fig. 1b) that were recorded by an amphibious seismic network operated in the framework of the European AlpArray initiative (Hetényi et al., 2018). The AlpArray OBS network, a long-term ocean bottom broadband seismometer (OBS) array, recorded

ground motion continuously for 8 months. The deployment of long-term OBS enables robust source estimates of earthquakes far away from land stations. Nevertheless, observations from the land stations improved the estimate of fault plane solutions. The observed earthquake clusters and their depth distribution provide constraints on the crust and upper mantle rheology and provide insights into today's regional stress field.

\section{Geological and geodynamic setting}

50 The Western Mediterranean, including the waters west of Apennines and Sicily, consists of several basins (Fig. 2) that formed from Oligo-Miocene times to the present (e.g. Burrus, 1984; Rehault et al., 1984). The geodynamic setting is controlled by the convergence of the African and Eurasian plates (e.g. Dercourt et al., 1986) and the rollback of the Apennines and Calabrian subduction zones (Jolivet and Faccenna, 2000). The fast rollback of the westward migrating Gibraltar arc and the eastward migrating Apennines arc played a major role in the opening of the Mediterranean sub-basins (Lamotte et al., 2000; Mauffret

55 et al., 2004; Handy et al., 2010). The Ligurian Basin, opening 30-16 Ma (Burrus, 1984; Bache et al., 2010), and the Alboran Basin, opening 25-20 Ma (Faccenna et al., 2004), are the oldest basins in the Western Mediterranean. The Algerian Basin, opening 16-8 Ma (Mauffret et al., 2004), and the Tyrrhenian Basin, opening 8-0 Ma (Faccenna et al., 2001; Rosenbaum et al., 2002), are the youngest basins in the Western Mediterranean. In the latter two basins, geophysical and geological data clearly show that extension caused break-up and seafloor spreading (Nicolosi et al., 2006; Bouyahiaoui et al., 2015; Prada et

60 al., 2016; Booth-Rea et al., 2018), while the Alboran Sea is a domain of extended continental crust modulated by arc magmatism (Booth-Rea et al., 2018; Gómez de la Peña et al., 2020). The Balearic Sea is floored by oceanic crust (Gailler et al., 2009; Afilhado et al., 2015; Moulin et al., 2015). However, the extent and nature of the oceanic domain towards the northeast into the Liguro-Provencal Basin remains debated.

The Ligurian Basin underwent a long-lasting phase of extension from Late Oligocene to Miocene (Rehault et al., 1984;

65 Gueguen et al., 1998; Finetti et al., 2005), progressively opening from south to north. Based on magnetic and seismic data, oceanic spreading with unroofing of mantle material was proposed for the late opening period 21-16 Ma (Le Douaran et al., 1984; Pascal et al., 1993; Contrucci et al., 2001; Rollet et al., 2002; Speranza et al., 2002). For the Ligurian Basin, which is the NE part of the Liguro-Provencal Basin, a recent analysis of a seismic refraction profile proposes that rifting failed before oceanic spreading initiated (Dannowski et al., 2020). The Corsica-Sardinia block underwent a counter-clockwise (CCW)

70 rotation (Alvarez et al., 1973; Rehault et al., 1984; Speranza et al., 2002; Maffione et al., 2008) of $\sim 23^{\circ}$ over a short time $\sim 20$ $16 \mathrm{Ma}$ (Speranza et al., 2002) (Fig. 2). Extension in the Ligurian Basin ended 16 Ma and continued afterwards in the Algerian and Tyrrhenian basins (Mauffret et al., 2004). 
The Calabrian trench retreats further south-eastwards (Fig. 2, white arrow), however, recent seismological observations indicate that Tyrrhenian Sea opening ceased and the Africa-Eurasia convergence results in basin inversion at its southern rim (Zitellini et al., 2020). It is proposed that the major shortening caused by the convergence between Africa and Europe is accommodated in the Maghrebides ranges in North Africa (90-100\%) and that the Ligurian Basin and the Corsica-Sardinia block are rigid (Nocquet and Calais, 2004; Béthoux et al., 2008; Nocquet, 2012). However, passive seismic studies observe signatures of compression in the Ligurian Basin (Béthoux, 1992; Baroux et al., 2001; Eva et al., 2001; Courboulex et al., 2007; Béthoux et al., 2008; Larroque et al., 2012, 2016). Moreover, active compressional structures were imaged in seismic reflection profiles (Bigot-Cormier et al., 2004) offshore the Ligurian coast. Along the Corsica margin, seismic reflection data do not image significant seismic ruptures that reached the surface since $\sim 5 \mathrm{Ma}$, but earthquakes of $\mathrm{M}_{\mathrm{L}} 5.5$ and $\mathrm{M}_{\mathrm{L}} 4.4$ occurred in July 2011 offshore Corsica (Larroque et al., 2016) (Fig. 1, grey star). While the Ligurian margin is narrow and steep with a few listric normal faults, the Corsica margin is wider and several listric faults were imaged in seismic reflection data (Finetti et al., 2005). Within a short distance of $30-50 \mathrm{~km}$, the crust-mantle boundary (CMB) deepens from $\sim 15 \mathrm{~km}$ depth in the basin to $25 \mathrm{~km}$ depth at the continental margins (Contrucci et al., 2001; Gailler et al., 2009; Dessa et al., 2011).

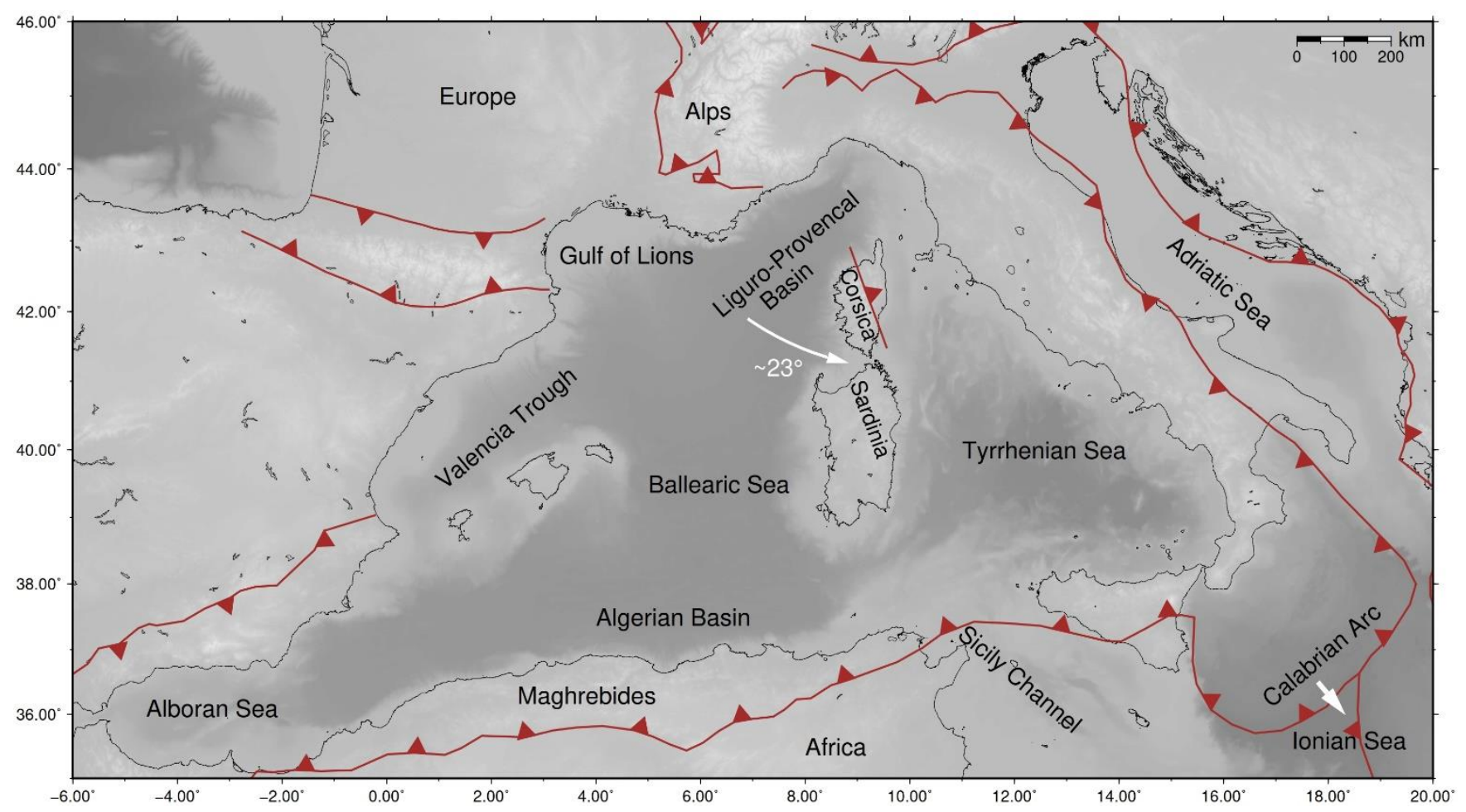

Figure 2: Geographic and tectonic overview map with thrusts modified from Le Breton et al. (2020). The white arrows indicate the $\sim 23^{\circ} \mathrm{CCW}$ rotation of the Corsica-Sardinia block during Miocene times (Speranza et al., 2002) and the trench retreat of the 
https://doi.org/10.5194/se-2021-9

Preprint. Discussion started: 5 February 2021

(C) Author(s) 2021. CC BY 4.0 License.

\section{(c) (i)}

\section{Data and results}

The AlpArray OBS network consisted of 24 broadband OBS (Fig. 1) that continuously recorded ground motion for $\sim 8$ months (June 2017 to February 2018). The stations were deployed with a spacing of $\sim 60 \mathrm{~km}$ using the French research vessel "Pourquoi Pas?" and recovered during research cruise MSM71 on the German research vessel "Maria S. Merian". Data from two OBS

95 instruments types were used in our study: (1) German OBS, provided by the DEPAS pool and GEOMAR (Lobster type), equipped with a Trillium Compact 120 s seismometer and an HTI-04-PCA/ULF hydrophone recording on 6D6 KUM recorders with a sampling frequency of $250 \mathrm{~Hz}$. (2) French OBS, provided by the IPGP-INSU pool (BBOBS), equipped with a Trillium $240 \mathrm{~s}$ seismometer (T240) and a differential pressure gauge (DPG) recording at a frequency of 62.5 Hz. Additionally, land data (Fig. 1) were used from different regional permanent and temporary seismological networks: AlpArray (Z3), Italian

100 National (IV), French RESIF-RLBP (FR) and Mediterranean MedNet (MN).

\subsection{Events, picking and location}

During the long-term OBS deployment, 39 seismic events were detected within the Ligurian Basin excluding the Alps-Liguria junction zone (Fig. 1a, magenta circles). Our work focuses on two earthquake clusters in the centre of the Ligurian Basin, near OBS A423A (magenta circles in Fig. 1b; Table 1). The first cluster (C1) consists of 13 events that occurred from June to

105 November 2017 (Fig. 3a, blue bars). The second cluster (C2) consists of three events that occurred during one day in January 2018, about $25 \mathrm{~km}$ southwest of C1 (Fig. 3a, red bars). Two events (grey bars in figure 3a) had few observations and high uncertainties, they were not used in this interpretation. Two more small events were only observed at station A423A and were not further analysed (Fig. 3a, black bars). We show that a seafloor network could detect more events than those in the ISC catalogue (Tab. 1), whose magnitude of completeness is 2.2 in the region, but the four events (grey and black bars in Fig. $3 \mathrm{a}$ )

110 indicate that the AlpArray OBS station spacing is too large to render a more precise picture of the local seismicity. Initially, the ISC bulletin (Storchak et al., 2017) was used to detect seismic events in the AlpArray OBS data. The phases were picked manually on all stations plotted with orange triangles, orange squares and white hexagons in Figure 1b. Only the seismometer components were used in our analysis since the signal-noise ratio on most of the hydrophones was too low to identify local seismic events.

115 Three onsets predominated the observed events: the P-wave, a converted Ps-wave and the S-wave (Fig. 3b). The P-wave is weak in amplitude and followed by a stronger Ps-phase. Both phases indicate an apparent P-wave velocity (Vp) of $\sim 8.1 \mathrm{~km} / \mathrm{s}$ and they are separated by a nearly constant time difference of $\sim 1 \mathrm{~s}$. The S-wave phase has a high amplitude, compared to the P-onsets, and shows an apparent S-wave velocity (Vs) of $\sim 4.7 \mathrm{~km} / \mathrm{s}$ (Fig. 3b). The waveforms are highly coherent as shown for the vertical component of station A423A (Fig. 4a). Picking was done for the P-onset on the vertical component and for the 120 S-onset on the horizontal components using SEISAN (Havskov and Ottemoller, 1999).

Within cluster $\mathrm{C} 1$, two main families of waveforms are observed indicating a repeated activation of the fault. Family 1 was active in June 2017 and consists of events 2, 3, and 4. Family 2 was active at the end of August and again in September 2017 
https://doi.org/10.5194/se-2021-9

Preprint. Discussion started: 5 February 2021

(c) Author(s) 2021. CC BY 4.0 License.

and consists of events 5 to 10,12 , and 13. Cluster C2 consists of a third waveform family, events 16 to 18 . The coherency within the families is $>0.8$.

(a)

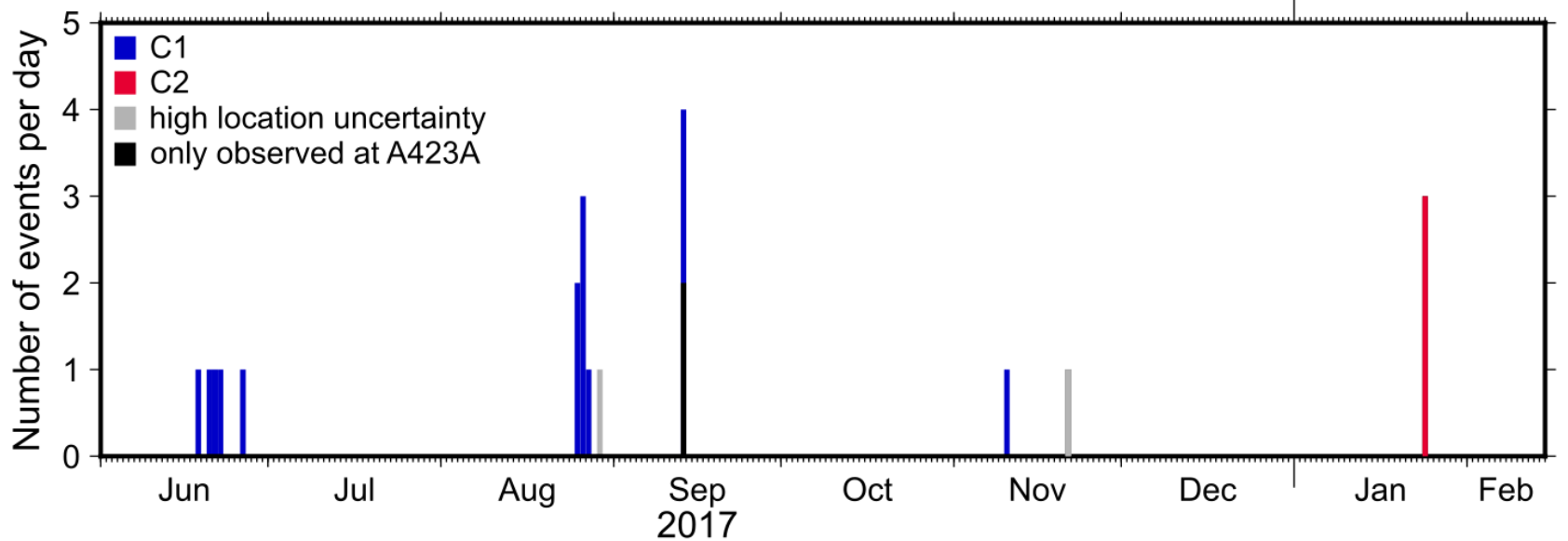

(b)

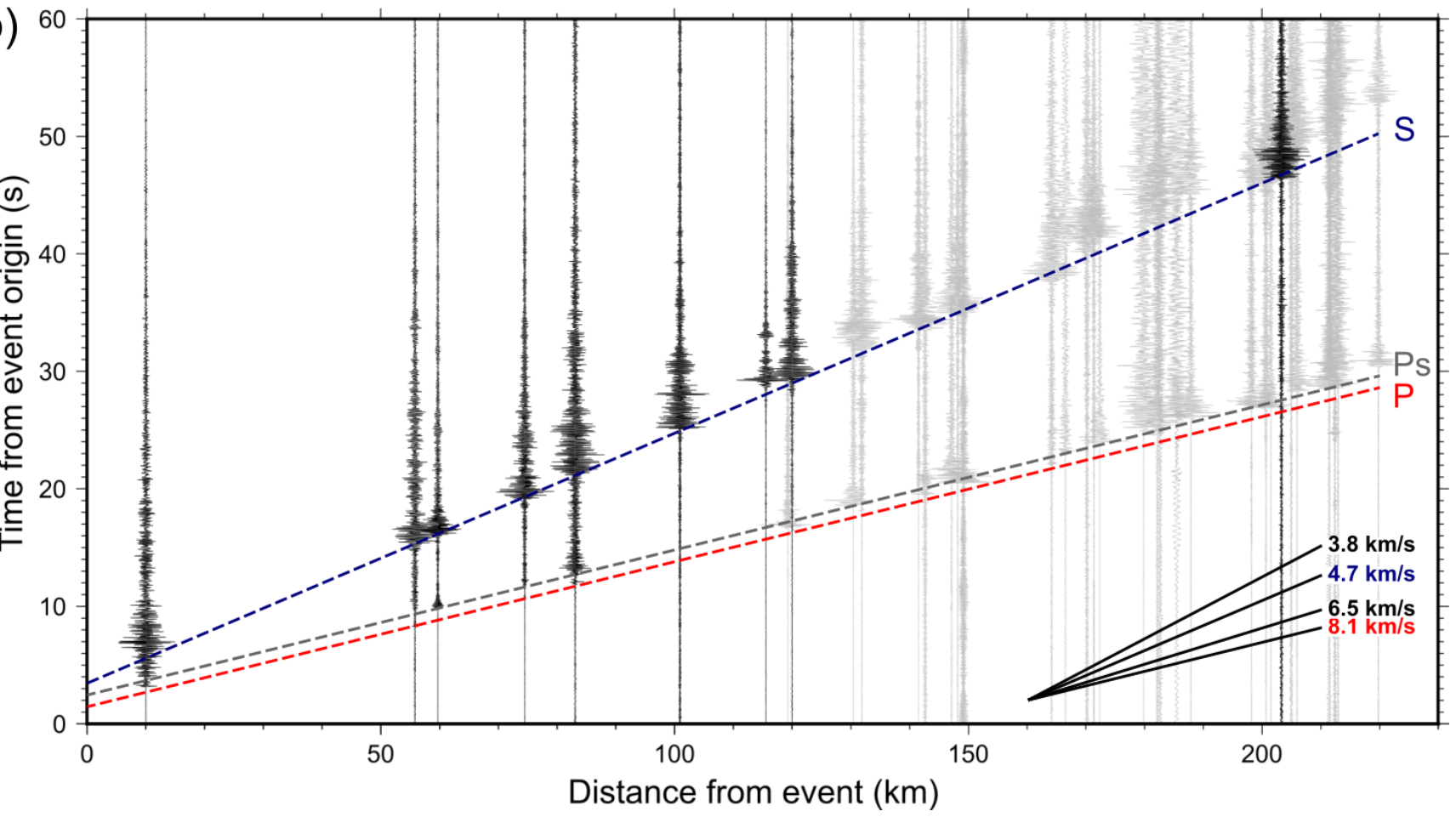

Figure 3: Panel (a) shows the temporal development of the cluster events in blue for $\mathrm{C} 1$ and in red for C2. Black events were only observed at A423A and not further analysed. Grey events were located with high uncertainties. (b) Waveforms of the strongest event of C1 (20.06.2017) displayed over offset. Black traces were used for EQ location. A weak P onset (red line) is observed, followed by a stronger Ps phase (grey line) $\sim 1 \mathrm{~s}$ later. The $\mathrm{S}$ phase (blue line) is well visible at all stations. Apparent velocities of $\mathrm{Vp}=8.1 \mathrm{~km} / \mathrm{s}$ and $V s=4.7 \mathrm{~km} / \mathrm{s}$ are observed for the phase onsets.

We use only stations within the basin (orange triangles in Fig. 1) to locate the events. In this way, we can use a 1-D seismic velocity model for the basin and avoid errors introduced by the extreme topography and changes in crustal thickness near the 
https://doi.org/10.5194/se-2021-9

Preprint. Discussion started: 5 February 2021

margins. We applied the 1-D velocity model (Fig. 4b) that is based on P-wave velocities from the seismic refraction profile p02 (Dannowski et al., 2020) (Fig. 5e). A Vp/Vs ratio of 2.0 at the seafloor and 1.87 above the CMB was assumed to convert

135 Vp to Vs (Fig. 4b). The observed apparent velocities of mantle refracted waves Pn and Sn (Fig. 3b) were used as Vp and Vs for the uppermost mantle in the 1-D velocity models (Fig. 4b). After an initial event location, using SEISAN (Havskov and Ottemoller, 1999), events of the two clusters were relocated with hypoDD, a double-difference earthquake algorithm for relative relocations (Waldhauser and Ellsworth, 2000). Because our clusters containing only a few events and the background velocity model is well-constrained, we used hypoDD's singular value decomposition (SVD) solver.

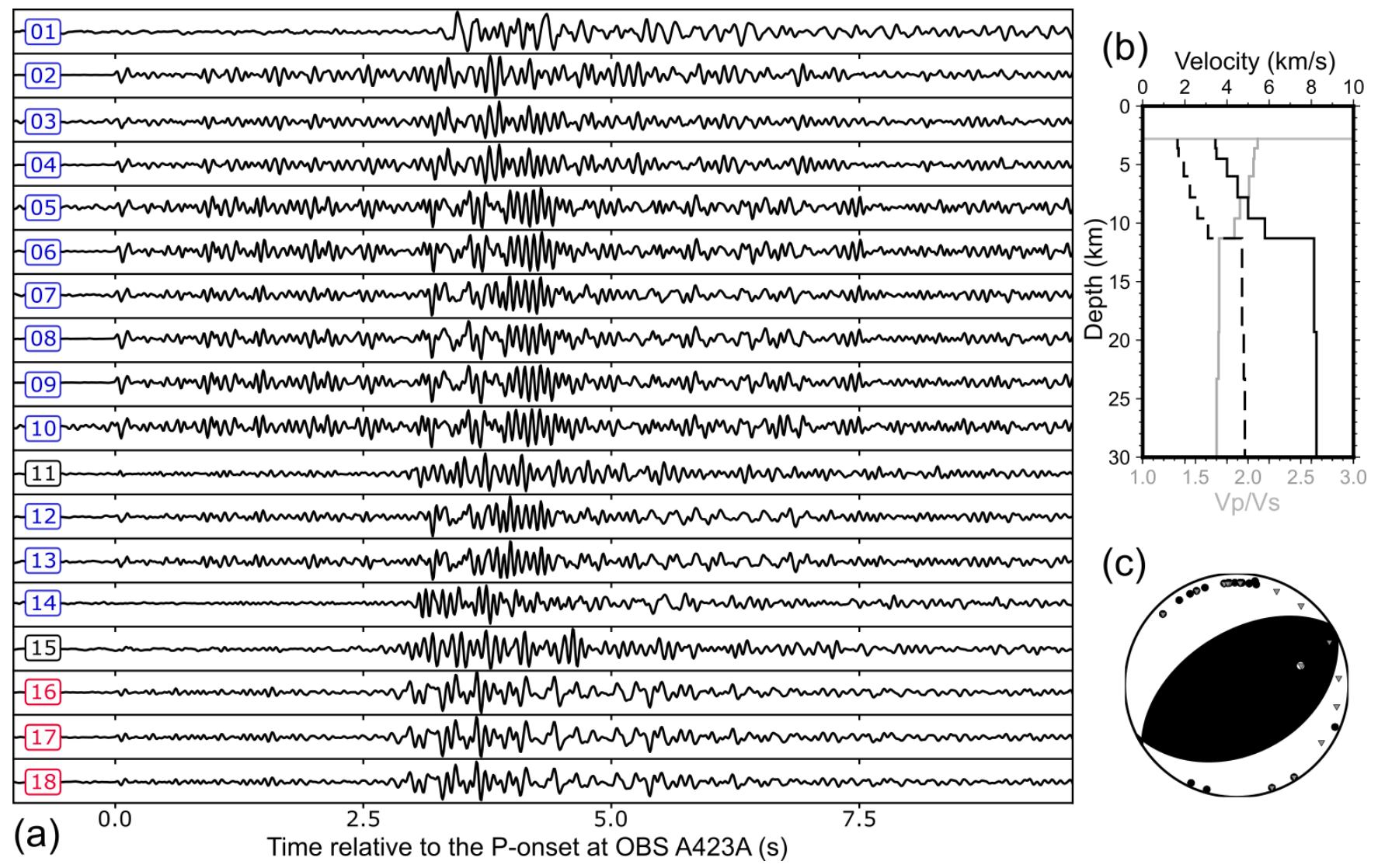

Figure 4: (a) All observed cluster events recorded at station A423A, Z-component (bandpass filtered 2-20 Hz). The P-onsets are shifted so that they align at $\mathrm{O}$ s. (b) 1-D velocity models ( Vp, solid line, Vs, dashed line, and Vp/Vs grey solid line) used to relocate the cluster events. (c) Focal mechanism of event 2, computed using the amplitude ratio of Sv/P (grey inverted triangles) and the wave polarisation (black dots for negative polarisation) determined at OBS and land stations.

145 Epicentres of events observed in both the ISC bulletin and our study, were compared. Pairs are connected by black lines in the seismicity map (Fig. 1). The epicentres based on the ISC bulletin are spread over a 50x20 km zone. In contrast, the same events located solely based on OBS data plot in a very narrow $3 \times 3 \mathrm{~km}$ zone (Fig. 1b and 5b). Additional events with magnitude $\mathrm{M}_{\mathrm{L}}$ $<2$ were detected using the OBS; these events were also recorded by the land stations (Fig. 1) but their amplitudes were close to the noise level. 
https://doi.org/10.5194/se-2021-9

Preprint. Discussion started: 5 February 2021

150 Table 1: Epicentral locations and focal depths for the cluster events from hypoDD (depth below sea surface). Magnitudes and focal mechanisms were computed for events that show clear wave polarities.

\begin{tabular}{|c|c|c|c|c|c|c|c|c|}
\hline Event ID & Date & Time of origin & Latitude & Longitude & Depth (km) & Magnitude $\left(\mathrm{M}_{\mathrm{L}}\right)$ & ISC bulletin ID & Cluster \\
\hline 1 & 2017-06-18 & $20: 55: 29.48$ & 42.194983 & 7.081169 & $10.4 \pm 0.2$ & 1.2 & 610697551 & $\mathrm{C} 1$ \\
\hline 2 & 2017-06-20 & 17:09:51.36 & 42.203548 & 7.078639 & $15.6 \pm 0.1$ & 2.5 & 610697576 & $\mathrm{C} 1$ \\
\hline 3 & 2017-06-21 & 02:28:07.10 & 42.207711 & 7.077632 & $15.1 \pm 0.1$ & 1.2 & 610779982 & $\mathrm{C} 1$ \\
\hline 4 & 2017-06-22 & 08:06:29.84 & 42.201794 & 7.079651 & $14.9 \pm 0.1$ & 1.4 & 610780001 & $\mathrm{C} 1$ \\
\hline 5 & $2017-08-25$ & 02:19:23.09 & 42.202787 & 7.069184 & $13.5 \pm 0.4$ & 1.3 & 611003163 & $\mathrm{C} 1$ \\
\hline 6 & $2017-08-25$ & $02: 33: 43.42$ & 42.202987 & 7.071468 & $16.1 \pm 0.1$ & 2.1 & 611003164 & $\mathrm{C} 1$ \\
\hline 7 & 2017-08-26 & $02: 26: 50.22$ & 42.202734 & 7.065569 & $15.2 \pm 0.2$ & 0.9 & 611003237 & $\mathrm{C} 1$ \\
\hline 8 & 2017-08-26 & 02:30:33.03 & 42.201440 & 7.069776 & $16.1 \pm 0.1$ & 1.9 & 611003238 & $\mathrm{C} 1$ \\
\hline 9 & 2017-08-26 & $17: 31: 51.84$ & 42.202738 & 7.070272 & $16.3 \pm 0.1$ & 1.9 & 610933407 & $\mathrm{C} 1$ \\
\hline 10 & $2017-08-27$ & 00:39:30.31 & 42.200989 & 7.069771 & $16.0 \pm 0.3$ & 1.3 & 611003290 & $\mathrm{C} 1$ \\
\hline 11 & 2017-08-29 & 11:54:17.80 & 42.1850 & 7.1040 & $8.4 \pm 5.2$ & 1.1 & & - \\
\hline 12 & 2017-09-13 & 07:47:16.31 & 42.205314 & 7.065561 & $16.5 \pm 0.1$ & 1.3 & & $\mathrm{C} 1$ \\
\hline 13 & 2017-09-13 & 09:26:57.97 & 42.207292 & 7.069896 & $15.9 \pm 0.1$ & 1.2 & & $\mathrm{C} 1$ \\
\hline 14 & $2017-11-10$ & $23: 05: 48.52$ & 42.204736 & 7.064332 & $14.4 \pm 0.1$ & 1.3 & 611617247 & $\mathrm{C} 1$ \\
\hline 15 & $2017-11-21$ & $11: 45: 24.00$ & 42.2080 & 6.8180 & $6.0 \pm 3.8$ & 0.9 & & - \\
\hline 16 & 2018-01-24 & $05: 11: 25.24$ & 42.089022 & 6.894502 & $9.9 \pm 0.4$ & 1.4 & & $\mathrm{C} 2$ \\
\hline 17 & 2018-01-24 & $07: 35: 48.27$ & 42.089233 & 6.892409 & $9.9 \pm 0.6$ & 1.4 & & $\mathrm{C} 2$ \\
\hline 18 & 2018-01-24 & 09:43:10.11 & 42.091915 & 6.894325 & $10.5 \pm 0.4$ & 1.2 & & $\mathrm{C} 2$ \\
\hline
\end{tabular}

\subsection{Focal mechanisms}

To estimate fault plane solutions we used the stations shown in orange in figure 1. The station distribution provided a good azimuthal coverage for the Ligurian Sea. Additionally, the permanent station VSL in southern Sardinia (located outside the map of Fig. 1a) was used. The first motion direction of the P-wave was determined for on- and offshore stations where clearly visible. The amplitude ratio of $\mathrm{P}$ - and S-wave was determined on the vertical component at land stations only. The ocean bottom stations showed unusual small amplitudes for the P-wave compared to the S-wave, indicating systematic faulty recording. Polarity and amplitude ratios were used to derive the fault plane solution of events 2, 6, 8, and 9 (Fig. 4; Tab. 1) by means of the program FOCMEC (Snoke, 2003). In general, the events of cluster C1 show stronger amplitudes compared to $\mathrm{C} 2$. The four fault plane solutions of cluster $\mathrm{C} 1$ indicate thrust faulting (Fig. 4c and Fig. 5a). The arrivals from events of C2 were not of sufficient quality to calculate focal mechanisms. 

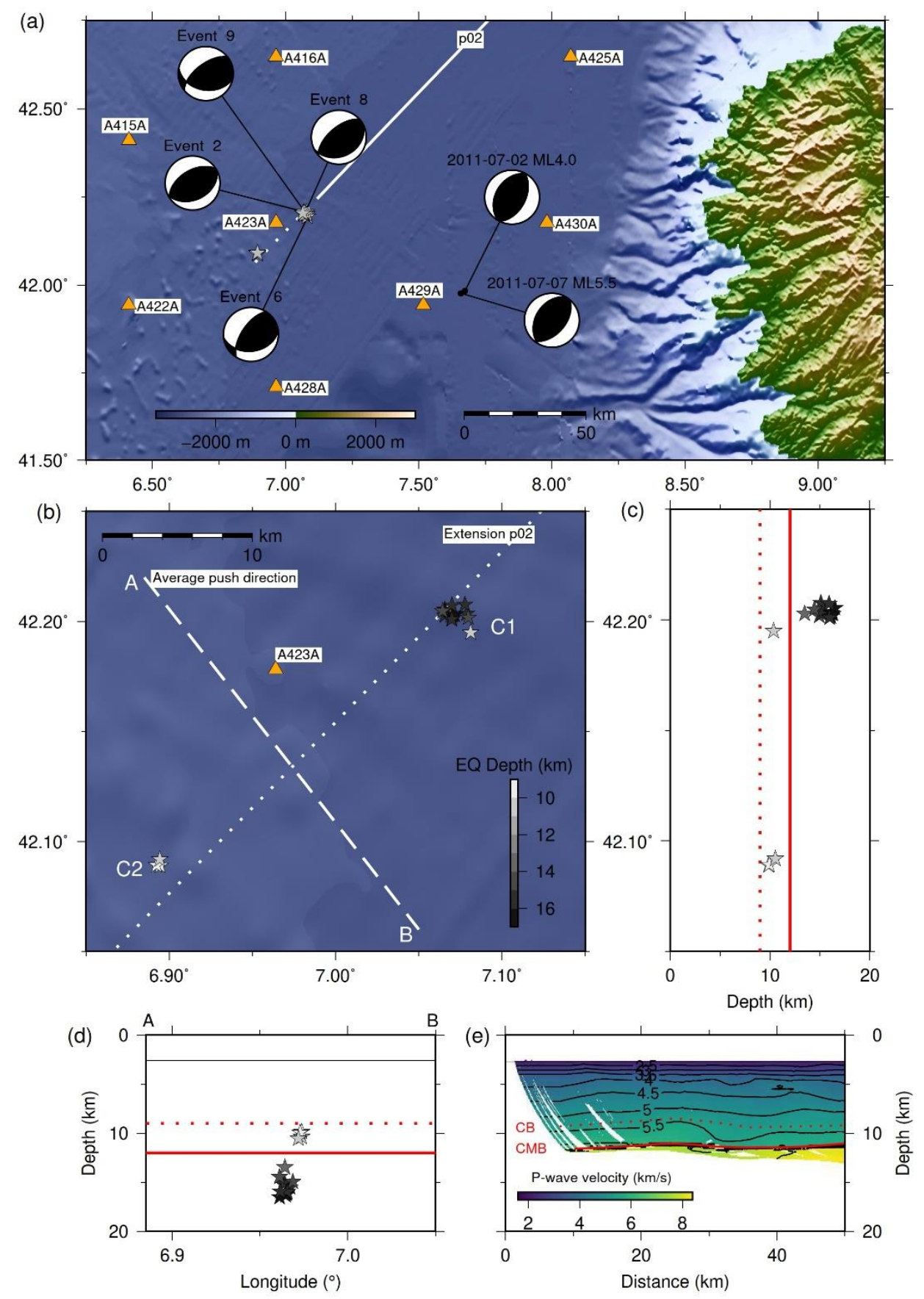

Figure 5: (a) Focal mechanisms of $\mathrm{C} 1$ cluster and two events in 2011 (Larroque et al., 2016). (b) Zoom into the map from panel a. 165 The white dotted line indicates the prolongation of seismic refraction profile p02 (white line in panel a) and the white dashed line represents the main horizontal direction of the pressure axis $\mathbf{P}$ as indicated by focal mechanisms. (c) Depth distribution of the cluster events from North to South. (d) Events projected on the dashed line A-B shown in panel b. The thin black line indicates the seafloor, the dotted red line is the crystalline basement $(\mathrm{CB})$ and the solid red line is the crust-mantle boundary (CMB). (e) SW end of the seismic velocity model computed from seismic refraction profile p02 (Dannowski et al., 2020). Topography from GMRT data (Ryan et al., 2009). 
https://doi.org/10.5194/se-2021-9

Preprint. Discussion started: 5 February 2021

(c) Author(s) 2021. CC BY 4.0 License.

\section{(c) (1)}

\section{Discussion}

\subsection{Basin inversion}

Geodetic measurements in Corsica and Sardinia show residual velocities $<0.5 \mathrm{~mm} / \mathrm{y}$ with respect to stable Europe (Nocquet and Calais, 2004), which the authors use to conclude that the shortening at the Alps-Liguria junction, expressed in widely distributed low- to moderate-magnitude earthquakes, is a result of the ongoing CCW rotation of the Adriatic microplate, rather than a S-N motion of the Corsica-Sardinia block. Further, Larroque et al. (2016) observed an earthquake cluster in 2011 offshore Corsica (Fig. 5a) accompanied by events in 2012 and 2013 located in the same area, but they did not observe surface ruptures nor faults rupturing the Plio-Quaternary sediments in the epicentre area of the 2011 events. Inspired by their analysis, we studied the seafloor bathymetry in the $\mathrm{C} 1 / \mathrm{C} 2$ region and observed no fault structure. Nor do pre-existing multi-channel seismic data map sufficiently large faults in the sedimentary strata. The $\mathrm{C} 1$ and $\mathrm{C} 2$ events are smaller than the 2011 events and occurred at similar focal depth. Thus, we assume that the rupture is entirely located within the lower crust and uppermost mantle and does not reach post-rift sediments. This suggests a long-term deformation without cumulating slip concentrated in one fault plane but rather distributed rupture areas.

Larroque et al. (2016) debated whether the 2011 cluster results from ridge-push forces of an oceanic spreading centre in the

185 Ligurian Basin or a southward propagation of the deformation at the Alps-Liguria junction. They exclude the hypothesis of a spreading centre, since no spreading axis had been mapped. Our study corroborates this hypothesis, since clusters $\mathrm{C} 1$ and $\mathrm{C} 2$ are located in the basin centre and would be even closer to or at the proposed spreading axis and so ridge-push forces would be higher. Additionally, no spreading axis was mapped in more recent seismic studies and the LOBSTER seismic refraction profile p02 (Dannowski et al., 2020) proposes that rifting failed before seafloor spreading was initiated.

190 To summarise previous studies, sources for the regional compressional stresses could be: (1) Africa-Europe convergence, (2) CCW rotation of the Adriatic plate (Larroque et al., 2016), or (3) north-eastward motion of the Tyrrhenian Sea towards stable Europe (Nocquet, 2012). Geodetic stations in Northern Africa are still missing, excluding reliable constraints on plate motions based on geodetic measurements (Nocquet, 2012). The latest plate motion models (Nocquet, 2012; Le Breton et al., 2017, 2020; van Hinsbergen et al., 2020) are based on seismicity and other geophysical and geological information and indicate that

195 the majority (90-100\%) of Europe-Africa convergence is accommodated in the Maghrebides. The Ligurian Basin and the Corsica-Sardinia block are seen as rigidly attached to stable Europe (Nocquet, 2012).

The epicentres of cluster $\mathrm{C} 1$ were located in the uppermost mantle (one event in the lower crust) and their mechanisms are thrust faulting (Fig. 5), while the epicentres of cluster C2 were located in the lower crust, above the CMB. The 2011 events were also thrust faulting events which occurred in the crust and uppermost mantle (Larroque et al., 2016), roughly $50 \mathrm{~km} \mathrm{E-}$

200 SE of clusters $\mathrm{C} 1$ and $\mathrm{C} 2$. If we project $\mathrm{C} 1$ and $\mathrm{C} 2$ on line $\mathrm{A}-\mathrm{B}$ that follows the push direction of the thrust events, they map in a slightly tilted vertical plane dipping south-eastwards (Fig. 5d). Independently of the source of regional stresses, we interpret the $\mathrm{C} 1$ and $\mathrm{C} 2$ clusters and the 2011 cluster as a result of basin inversion and hence a reactivation of the OligoceneMiocene rifting structures. The basin inversion in the Ligurian Basin is characterised by a diffuse distribution of rupture areas 
https://doi.org/10.5194/se-2021-9

Preprint. Discussion started: 5 February 2021

(c) Author(s) 2021. CC BY 4.0 License.

(c) (i)

of small size spread over a wide area in the basin centre. Shortening in the Ligurian Basin can be taken up by these remaining rifting structures, enabling the closure of the Ligurian Basin. Our results show that today's observed seismicity based on land stations underestimate the number of earthquakes in the Algerian and Ligurian basins. Reactivation of pre-existing and often rifting-related fault planes was observed in other areas, for example in the Tyrrhenian Sea (Zitellini et al., 2020), in the Gulf of Cadiz (Grevemeyer et al., 2016) and in northern Honshu, Japan (Kato et al., 2009). Therefore, like the Tyrrhenian Sea (Zitellini et al., 2020), the Ligurian Sea may have entered a stage of basin inversion.

\section{$210 \quad 4.2$ Implications on rifting history}

While earthquakes are spread over the entire Ligurian Basin (Fig. 1), the $\mathrm{C} 1$ and $\mathrm{C} 2$ events cluster within small areas. $\mathrm{C} 1$ and $\mathrm{C} 2$ are separated by $\sim 25 \mathrm{~km}$ in a NE-SW direction, suggesting that both clusters may originate from the same fault zone. The focal mechanisms of cluster C1 are similar to the 2011 events (Larroque et al., 2016). In detail, we observe a difference of $\sim 15^{\circ}$ between the striking direction of the fault planes of $\mathrm{C} 1$ and the striking direction of the 2011 events. As discussed before,

215 we interpret the three clusters as caused by the reactivation of Oligocene-Miocene rifting structures. Normal faults that were created during the extensional phase are turned into reverse faults and their strikes are those of the normal faults during the extensional phase. Since the 2011 events are located more to the southeast, they represent an older phase of rifting compared to $\mathrm{C} 1$ and $\mathrm{C} 2$. Thus, we speculate that this difference in strike might be connected to the $23^{\circ} \mathrm{CCW}$ rotation of the CorsicaSardinia block compared to stable Europe that took place between 20-16 Ma (Speranza et al., 2002; Le Breton et al., 2017).

4.3 Rheology of crust and uppermost mantle

Earthquakes in continental domains normally occur in the upper crust, while the lower crust is relatively aseismic and earthquakes are rare in continental mantle lithosphere (Maggi et al., 2000). Whereas earthquakes certainly occur in oceanic crust and mantle lithosphere (Wiens and Stein, 1983). Similar to oceanic lithosphere, Maggi et al. (2000) suggest that the strength of continental lithosphere is controlled by the temperature structure and the amount of water in the formation and resides in one seismogenic layer within the crust. They propose that continental mantle lithosphere is relatively weak, and thus, aseismic. However, episodes of rifting may affect crustal and mantle rheology.

Rifting models suggest that the rheology of the continental domain changes during extension at non-volcanic rifted margins (Pérez-Gussinyé and Reston, 2001). With increasing stretching, the portion of the crust that becomes brittle increases. Stretching of the lithosphere will cause lower temperatures at the crust-mantle boundary, which in turn, will strengthen the

230 entire crust. When the entire crust is brittle, faults can cut through the crust into the mantle and act as fluid pathways, a precondition to initiate mantle serpentinisation during rifting (Pérez-Gussinyé and Reston, 2001). The serpentinites create a weak base of the crust, enabling detachment along the $\mathrm{CMB}$ and crustal fault block rotation. The serpentine thickness increases with increasing rift duration until the final break-up of the continent (Pérez-Gussinyé and Reston, 2001). 
https://doi.org/10.5194/se-2021-9

Preprint. Discussion started: 5 February 2021

(c) Author(s) 2021. CC BY 4.0 License.

(c) (i)

The cluster events discussed here are interpreted to reflect pre-existing normal faults generated during rifting. We recognise a good relationship between our data and the rifting model of Pérez-Gussinyé and Reston (2001), suggesting that the entire continental crust may have evolved into a brittle domain during extension. The $\mathrm{C} 1$ events at mantle depths are more puzzling. Earthquakes within continental mantle lithosphere were also observed in the Gulf of Cadiz, in the southern Iberian old Jurassic mantle lithosphere (Grevemeyer et al., 2016). An explanation could be that during extension, mantle material moves closer to the surface than before stretching, causing mantle temperatures to decrease (Sandiford, 1999). Thus, the mantle in the basin centre might become stronger and more brittle than the surrounding mantle (Sandiford, 1999). Such a scenario is supported by cluster $\mathrm{C} 1$ occurring in the uppermost mantle and supporting a low Vp/Vs-ratio of 1.72 (Fig. 4b). The crustal structure in the vicinity of clusters $\mathrm{C} 1$ and $\mathrm{C} 2$ is well imaged by the LOBSTER seismic refraction profile p02 (Dannowski et al., 2020), which provides no indication of a high amount of mantle serpentinisation at its southern end. A high sedimentation rate during rifting may have prevented water from penetrating down to the mantle (Rüpke et al., 2013), minimising serpentinisation. However,

245 water may have occasionally reached the mantle, causing serpentinisation around some rift-related faults and weakening the mantle locally (Pérez-Gussinyé and Reston, 2001), possibly enabling the reactivation of rifting-related normal faults as reverse faults.

High heat flow (>100 mW/m²) in the Ligurian Basin (Pasquale et al., 1994) may contradict a cool CMB at the basin centre. However, Hansen and Nielsen (2002) showed that a combination of a very thick sedimentary cover $(>8 \mathrm{~km})$, extremely low 250 conductive sediments $(<1.5 \mathrm{~W} / \mathrm{mK})$ and very shallow and localised crustal radiogenic heat production allow for a temperature maximum at the CMB beneath the basin centre. The thick sedimentary cover in the Ligurian Basin (up to $7 \mathrm{~km}$, Schettino and Turco, 2006) might cause thermal blanketing, reducing the lithospheric heat loss, in line with the observed high heat flow values in the basin centre compared to the margins.

\section{Conclusions}

255 The entire Ligurian Basin is characterised by sparse but wide-spread micro-earthquakes of magnitude <3. A 2017-2018 oceanbottom seismometer deployment recorded two earthquake clusters that show thrust faulting mechanisms, supporting a model of inversion of the Ligurian Basin, in which the basin's centre is under compression and stresses are taken up by reactivated faults in the crust and uppermost mantle. Compressional forces are probably related to Africa-Europe plate convergence. The location of the cluster events and their focal mechanisms indicate that they occurred in reactivated pre-existing rift structures.

260 Slightly different striking directions of faults in the basin centre compared to faults further east and hence away from the abandoned rift may mimic the counter-clockwise rotation of the Corsica-Sardinia block during 20-16 Ma. In general, observations of earthquakes in continental mantle lithosphere are rare. Here, they reveal a strengthening of the crust and uppermost mantle during rifting and they support the interpretation that rifting failed in the northern Ligurian Basin. Additional 
https://doi.org/10.5194/se-2021-9

Preprint. Discussion started: 5 February 2021

(c) Author(s) 2021. CC BY 4.0 License.

(c) (i)

Discussions

data from an array of more densely spaced OBS would be needed to obtain a more complete picture of local seismicity in the basin centre.

\section{Acknowledgements}

We thank the captain and crew of the R/V Maria S. Merian (cruise MSM71, 7-27 February 2018) and the R/V Pourquoi Pas? (AlpArray cruise, 14-26 June 2017). We thank the cruise participants of both cruises for their efforts. OBS were provided by the DEPAS pool, GEOMAR, and IPGP-INSU pool. The deployment of the German component of the AlpArray seismic network (AASN) was funded by the LOBSTER project that is part of the German Priority Programme SPP2017 4D-MB. The deployment of the French component of the AASN was funded by the AlpArray-FR project of the Agence Nationale de la Recherche (contract ANR-15-CE31-0015). We also thank the AlpArray Seismic Network Team (http://www.alparray.ethz.ch/en/seismic_network/backbone/data-policy-and-citation/) and the permanent seismic networks used in this study (FR, IV, and MN). Figures were created using Generic Mapping Tools version 6 (Wessel et al., 2019) and 275 Inkscape (www.inkscape.org).

\section{Financial support}

This research has been supported by the Deutsche Forschungsgemeinschaft (DFG), grant no. TH_2440/1-1, KO_2961/6-1, and LA_2970/4-1. The deployment of the French component of the AlpArray seismic network (AASN) was funded by the AlpArray-FR project of the Agence Nationale de la Recherche (contract ANR-15-CE31- 0015).

\section{Data availability}

Data from the temporary and permanent land stations as well as the OBS are available through the AlpArray seismic network (Z3, http://data.datacite.org/10.12686/alparray/z3_2015), the Italian network (IV, http://doi.org/10.13127/SD/X0FXnH7QfY), the French RESIF-RLBP network (FR, http://doi.org/10.15778/RESIF.FR), and the Mediterranean MedNet network (MN, https://doi.org/10.13127/SD/fBBBtDtd6q).

\section{Competing interests}

The authors declare that they have no conflict of interest. 
https://doi.org/10.5194/se-2021-9

Preprint. Discussion started: 5 February 2021

(C) Author(s) 2021. CC BY 4.0 License.

(c) (i)

\section{Author contributions}

MT carried out data analysis and contributed to the manuscript. AD wrote the manuscript and contributed to the data analysis. $\mathrm{AD}$ and MT created the figures. IG contributed to the manuscript with in depth discussion and manuscript editing. HK was PI 290 of the research cruise MSM71 with R/V Maria S. Merian. WC was PI of the AlpArray cruise with R/V Pourquoi Pas?. HK, DL, IG, MT, AP, WC acquired funding and planned the research concept. HK, AD, FP, MT, DL, AP participated in cruise MSM71 onboard R/V Maria S. Merian. WC, FP, AP deployed the AlpArray OBS network on board the R/V Pourquoi Pas?.

\section{Team list}

The complete member list of the AlpArray Working Group can be found at:

http://www.alparray.ethz.ch/en/seismic_network/backbone/data-policy-and-citation/.

\section{References}

Afilhado, A., Moulin, M., Aslanian, D., Schnürle, P., Klingelhoefer, F., Nouzé, H., Rabineau, M., Leroux, E. and Beslier, M.O.: Deep crustal structure across a young passive margin from wide-angle and reflection seismic data (The SARDINIA Experiment) - II. Sardinia's margin, Bulletin de la Société Géologique de France, 186(4-5), 331-351, 300 https://doi.org/10.2113/gssgfbull.186.4-5.331, 2015.

Alvarez, W., Franks, S. G. and Nairn, A. E. M.: Palaeomagnetism of Plio-Pleistocene Basalts from North-west Sardinia, Nature Physical Science, 243(123), 10-11, https://doi.org/10.1038/physci243010a0, 1973.

Bache, F., Olivet, J. L., Gorini, C., Aslanian, D., Labails, C. and Rabineau, M.: Evolution of rifted continental margins: The case of the Gulf of Lions (Western Mediterranean Basin), Earth and Planetary Science Letters, 292(3-4), 345-356, https://doi.org/10.1016/j.epsl.2010.02.001, 2010.

Baroux, E., Béthoux, N. and Bellier, O.: Analyses of the stress field in southeastern France from earthquake focal mechanisms, Geophysical Journal International, 145(2), 336-348, https://doi.org/10.1046/j.1365-246x.2001.01362.x, 2001.

Béthoux, N.: Mécanismes au foyer et néotectonique; application à la mer Ligure (Méditerranée occidentale), quate, 3(3), 97104, https://doi.org/10.3406/quate.1992.1978, 1992.

310 Béthoux, N., Tric, E., Chery, J. and Beslier, M.-O.: Why is the Ligurian Basin (Mediterranean Sea) seismogenic? Thermomechanical modeling of a reactivated passive margin, Tectonics, 27(5), https://doi.org/10.1029/2007TC002232, 2008.

Bigot-Cormier, F., Sage, F., Marc, S., Déverchère, J., Ferrandini, M., Guennoc, P., Popoff, M. and Stéphan, J.-F.: Déformations pliocènes de la marge nord-Ligure (France) : les conséquences d'un chevauchement crustal sud-alpin - Pliocene deformation of the north-Ligurian margin (France): consequences of a south-Alpine crustal thrust, Bulletin de la Societe Geologique de 315 France, 175, 197-211, 2004.

Booth-Rea, G., R. Ranero, C. and Grevemeyer, I.: The Alboran volcanic-arc modulated the Messinian faunal exchange and salinity crisis, Scientific Reports, 8(1), 13015, https://doi.org/10.1038/s41598-018-31307-7, 2018. 
https://doi.org/10.5194/se-2021-9

Preprint. Discussion started: 5 February 2021

(c) Author(s) 2021. CC BY 4.0 License.

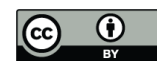

Bouyahiaoui, B., Sage, F., Abtout, A., Klingelhoefer, F., Yelles-Chaouche, K., Schnürle, P., Marok, A., Déverchère, J., Arab, M., Galve, A. and Collot, J. Y.: Crustal structure of the eastern Algerian continental margin and adjacent deep basin: 320 implications for late Cenozoic geodynamic evolution of the western Mediterranean, Geophysical Journal International, 201(3), 1912-1938, https://doi.org/10.1093/gji/ggv102, 2015.

Burrus, J.: Contribution to a geodynamic synthesis of the Provencal Basin (NorthWestern Mediterranean), Marine Geology, 55(3-4), 247-269, https://doi.org/10.1016/0025-3227(84)90071-9, 1984.

Contrucci, I., Nercessian, A., Béthoux, N., Mauffret, A. and Pascal, G.: A Ligurian (Western Mediterranean Sea) geophysical transect revisited, Geophysical Journal International, 146, 74-97, 2001.

Courboulex, F., Larroque, C., Deschamps, A., Kohrs-Sansorny, C., Gélis, C., Got, J. L., Charreau, J., Stéphan, J. F., Béthoux, N., Virieux, J., Brunel, D., Maron, C., Duval, A. M., Perez, J.-L. and Mondielli, P.: Seismic hazard on the French Riviera: observations, interpretations and simulations, Geophys. J. Int., 170(1), 387-400, https://doi.org/10.1111/j.1365246X.2007.03456.x, 2007.

330 Dannowski, A., Kopp, H., Grevemeyer, I., Lange, D., Thorwart, M., Bialas, J. and Wollatz-Vogt, M.: Seismic evidence for failed rifting in the Ligurian Basin, Western Alpine domain, Solid Earth, 11(3), 873-887, https://doi.org/10.5194/se-11-8732020, 2020.

Dercourt, J., Zonenshain, L. P., Ricou, L.-E., Kazmin, V. G., Le Pichon, X., Knipper, A. L., Grandjacquet, C., Sbortshikov, I. M., Geyssant, J., Lepvrier, C., Pechersky, D. H., Boulin, J., Sibuet, J.-C., Savostin, L. A., Sorokhtin, O., Westphal, M., 335 Bazhenov, M. L., Lauer, J. P. and Biju-Duval, B.: Geological evolution of the tethys belt from the atlantic to the pamirs since the LIAS, Tectonophysics, 123(1-4), 241-315, https://doi.org/10.1016/0040-1951(86)90199-X, 1986.

Dessa, J.-X., Simon, S., Lelievre, M., Beslier, M.-O., Deschamps, A., Bethoux, N., Solarino, S., Sage, F., Eva, E., Ferretti, G., Bellier, O. and Eva, C.: The GROSMarin experiment: three dimensional crustal structure of the North Ligurian margin from refraction tomography and preliminary analysis of microseismic measurements, Bulletin de la Societe Geologique de France,

340 182(4), 305-321, https://doi.org/10.2113/gssgfbull.182.4.305, 2011.

Eva, E., Solarino, S. and Spallarossa, D.: Seismicity and crustal structure beneath the western Ligurian Sea derived from local earthquake tomography, Tectonophysics, 339(3), 495-510, https://doi.org/10.1016/S0040-1951(01)00106-8, 2001.

Faccenna, C., Mattei, M., Funiciello, R. and Jolivet, L.: Styles of back-arc extension in the Central Mediterranean, Terra Nova, 9(3), 126-130, https://doi.org/10.1046/j.1365-3121.1997.d01-12.x, 1997.

345 Faccenna, C., Funiciello, F., Giardini, D. and Lucente, P.: Episodic back-arc extension during restricted mantle convection in the Central Mediterranean, Earth and Planetary Science Letters, 187(1-2), 105-116, https://doi.org/10.1016/S0012821X(01)00280-1, 2001.

Faccenna, C., Piromallo, C., Crespo-Blanc, A., Jolivet, L. and Rossetti, F.: Lateral slab deformation and the origin of the western Mediterranean arcs: ARCS OF THE MEDITERRANEAN, Tectonics, 23(1), https://doi.org/10.1029/2002TC001488, 3502004.

Finetti, I. R., Boccaletti, M., Bonini, M., Ben, A., Pipan, M., Prizzon, A. and Sani, F.: Lithospheric Tectono-Stratigraphic Setting of the Ligurian Sea-Northern Apennines-Adriatic Foreland from Integrated CROP Seismic Data, in Deep Seismic Exploration of the Central Mediterranean and Italy, CROP PROJECT, pp. 119-158, 2005. 
https://doi.org/10.5194/se-2021-9

Preprint. Discussion started: 5 February 2021

(c) Author(s) 2021. CC BY 4.0 License.

Gailler, A., Klingelhoefer, F., Olivet, J.-L. and Aslanian, D.: Crustal structure of a young margin pair: New results across the Liguro-Provencal Basin from wide-angle seismic tomography, Earth and Planetary Science Letters, 286(1-2), 333-345, https://doi.org/10.1016/j.epsl.2009.07.001, 2009.

Gómez de la Peña, L., Grevemeyer, I., Kopp, H., Díaz, J., Gallart, J., Booth-Rea, G., Gràcia, E. and Ranero, C. R.: The Lithospheric Structure of the Gibraltar Arc System From Wide-Angle Seismic Data, Journal of Geophysical Research: Solid Earth, 125(9), e2020JB019854, https://doi.org/10.1029/2020JB019854, 2020.

360 Grevemeyer, I., Matias, L. and Silva, S.: Mantle earthquakes beneath the South Iberia continental margin and Gulf of Cadiz constraints from an onshore-offshore seismological network, Journal of Geodynamics, 99, 39-50, https://doi.org/10.1016/j.jog.2016.06.001, 2016.

Gueguen, E., Doglioni, C. and Fernandez, M.: On the post-25 Ma geodynamic evolution of the western Mediterranean, Tectonophysics, 298(1-3), 259-269, https://doi.org/10.1016/S0040-1951(98)00189-9, 1998.

365 Handy, M. R., M. Schmid, S., Bousquet, R., Kissling, E. and Bernoulli, D.: Reconciling plate-tectonic reconstructions of Alpine Tethys with the geological-geophysical record of spreading and subduction in the Alps, Earth-Science Reviews, 102(34), 121-158, https://doi.org/10.1016/j.earscirev.2010.06.002, 2010.

Hansen, D. L. and Nielsen, S. B.: Does thermal weakening explain basin inversion?: Stochastic modelling of the thermal structure beneath sedimentary basins, Earth and Planetary Science Letters, 198(1), 113-127, https://doi.org/10.1016/S0012$370821 \mathrm{X}(02) 00471-5,2002$.

Havskov, J. and Ottemoller, L.: SeisAn Earthquake Analysis Software, Seismological Research Letters, 70(5), 532-534, https://doi.org/10.1785/gssrl.70.5.532, 1999.

Hetényi, G., Molinari, I., Clinton, J., Bokelmann, G., Bondár, I., Crawford, W. C., Dessa, J.-X., Doubre, C., Friederich, W., Fuchs, F., Giardini, D., Gráczer, Z., Handy, M. R., Herak, M., Jia, Y., Kissling, E., Kopp, H., Korn, M., Margheriti, L., Meier, 375 T., Mucciarelli, M., Paul, A., Pesaresi, D., Piromallo, C., Plenefisch, T., Plomerová, J., Ritter, J., Rümpker, G., Šipka, V., Spallarossa, D., Thomas, C., Tilmann, F., Wassermann, J., Weber, M., Wéber, Z., Wesztergom, V., Živčić, M., Abreu, R., Allegretti, I., Apoloner, M.-T., Aubert, C., Besançon, S., Bès de Berc, M., Brunel, D., Capello, M., Čarman, M., Cavaliere, A., Chèze, J., Chiarabba, C., Cougoulat, G., Cristiano, L., Czifra, T., D’Alema, E., Danesi, S., Daniel, R., Dannowski, A., Dasović, I., Deschamps, A., Egdorf, S., Fiket, T., Fischer, K., Funke, S., Govoni, A., Gröschl, G., Heimers, S., Heit, B., Herak,

380 D., Huber, J., Jarić, D., Jedlička, P., Jund, H., Klingen, S., Klotz, B., Kolínský, P., Kotek, J., Kühne, L., Kuk, K., Lange, D., Loos, J., Lovati, S., Malengros, D., Maron, C., Martin, X., Massa, M., Mazzarini, F., Métral, L., Moretti, M., Munzarová, H., Nardi, A., Pahor, J., Péquegnat, C., Petersen, F., Piccinini, D., Pondrelli, S., Prevolnik, S., Racine, R., Régnier, M., Reiss, M., Salimbeni, S., et al.: The AlpArray Seismic Network: A Large-Scale European Experiment to Image the Alpine Orogen, Surveys in Geophysics, 39(5), 1009-1033, https://doi.org/10.1007/s10712-018-9472-4, 2018.

385 van Hinsbergen, D. J. J., Torsvik, T. H., Schmid, S. M., Maţenco, L. C., Maffione, M., Vissers, R. L. M., Gürer, D. and Spakman, W.: Orogenic architecture of the Mediterranean region and kinematic reconstruction of its tectonic evolution since the Triassic, Gondwana Research, 81, 79-229, https://doi.org/10.1016/j.gr.2019.07.009, 2020.

Jolivet, L. and Faccenna, C.: Mediterranean extension and the Africa-Eurasia collision, Tectonics, 19(6), 1095-1106, https://doi.org/10.1029/2000TC900018, 2000.

390 Kato, A., Kurashimo, E., Igarashi, T., Sakai, S., Iidaka, T., Shinohara, M., Kanazawa, T., Yamada, T., Hirata, N. and Iwasaki, T.: Reactivation of ancient rift systems triggers devastating intraplate earthquakes, Geophysical Research Letters, 36(5), https://doi.org/10.1029/2008GL036450, 2009. 
https://doi.org/10.5194/se-2021-9

Preprint. Discussion started: 5 February 2021

(c) Author(s) 2021. CC BY 4.0 License.

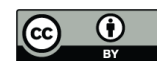

Lamotte, D. F. de, Bezar, B. S., Bracène, R. and Mercier, E.: The two main steps of the Atlas building and geodynamics of the western Mediterranean, Tectonics, 19(4), 740-761, https://doi.org/10.1029/2000TC900003, 2000.

395 Larroque, C., Scotti, O. and Ioualalen, M.: Reappraisal of the 1887 Ligurian earthquake (western Mediterranean) from macroseismicity, active tectonics and tsunami modelling: Reappraisal of the 1887 Ligurian earthquake, Geophysical Journal International, 190(1), 87-104, https://doi.org/10.1111/j.1365-246X.2012.05498.x, 2012.

Larroque, C., Delouis, B., Sage, F., Régnier, M., Béthoux, N., Courboulex, F. and Deschamps, A.: The sequence of moderatesize earthquakes at the junction of the Ligurian basin and the Corsica margin (western Mediterranean): The initiation of an 400 active deformation zone revealed?, Tectonophysics, 676, 135-147, https://doi.org/10.1016/j.tecto.2016.03.027, 2016.

Le Breton, E., Handy, M. R., Molli, G. and Ustaszewski, K.: Post-20 Ma Motion of the Adriatic Plate: New Constraints From Surrounding Orogens and Implications for Crust-Mantle Decoupling: Post-20 Ma Motion of the Adriatic Plate, Tectonics, 36(12), 3135-3154, https://doi.org/10.1002/2016TC004443, 2017.

Le Breton, E., Brune, S., Ustaszewski, K., Zahirovic, S., Seton, M. and Müller, R. D.: Kinematics and extent of the PiemontLiguria Basin \&ndash; implications for subduction processes in the Alps, Solid Earth Discussions, 1-42, https://doi.org/10.5194/se-2020-161, 2020.

Le Douaran, S., Burrus, J. and Avedik, F.: Deep structure of the north-western Mediterranean Basin: Results of a two-ship seismic survey, Marine Geology, 55(3-4), 325-345, https://doi.org/10.1016/0025-3227(84)90075-6, 1984.

Maffione, M., Speranza, F., Faccenna, C., Cascella, A., Vignaroli, G. and Sagnotti, L.: A synchronous Alpine and Corsica410 Sardinia rotation, Journal of Geophysical Research: Solid Earth, 113(B3), https://doi.org/10.1029/2007JB005214, 2008.

Maggi, A., Jackson, J. A., McKenzie, D. and Priestley, K.: Earthquake focal depths, effective elastic thickness, and the strength of the continental lithosphere, , 5, 2000.

Mauffret, A., Frizon de Lamotte, D., Lallemant, S., Gorini, C. and Maillard, A.: E-W opening of the Algerian Basin (Western Mediterranean), Terra Nova, 16(5), 257-264, https://doi.org/10.1111/j.1365-3121.2004.00559.x, 2004.

415 McKenzie, D. P. and Parker, R. L.: The North Pacific: an Example of Tectonics on a Sphere, Nature, 216(5122), 1276-1280, https://doi.org/10.1038/2161276a0, 1967.

Moulin, M., Klingelhoefer, F., Afilhado, A., Aslanian, D., Schnurle, P., Nouzé, H., Rabineau, M., Beslier, M.-O. and Feld, A.: Deep crustal structure across a young passive margin from wide-angle and reflection seismic data (The SARDINIA Experiment) - I. Gulf of Lion's margin, Bulletin de la Société Géologique de France, 186(4-5), 309-330, 420 https://doi.org/10.2113/gssgfbull.186.4-5.309, 2015.

Nicolosi, I., Speranza, F. and Chiappini, M.: Ultrafast oceanic spreading of the Marsili Basin, southern Tyrrhenian Sea: Evidence from magnetic anomaly analysis, Geology, 34(9), 717-720, https://doi.org/10.1130/G22555.1, 2006.

Nocquet, J.-M.: Present-day kinematics of the Mediterranean: A comprehensive overview of GPS results, Tectonophysics, 579, 220-242, https://doi.org/10.1016/j.tecto.2012.03.037, 2012.

425 Nocquet, J.-M. and Calais, E.: Geodetic Measurements of Crustal Deformation in the Western Mediterranean and Europe, Pure appl. geophys., 161(3), 661-681, https://doi.org/10.1007/s00024-003-2468-z, 2004. 
https://doi.org/10.5194/se-2021-9

Preprint. Discussion started: 5 February 2021

(c) Author(s) 2021. CC BY 4.0 License.

\section{(c) (i)}

Pascal, G. P., Mauffret, A. and Patriat, P.: The ocean-continent boundary in the Gulf of Lion from analysis of expanding spread profiles and gravity modelling, Geophysical Journal International, 113(3), 701-726, https://doi.org/10.1111/j.1365246X.1993.tb04662.x, 1993.

430 Pasquale, V., Verdoya, M. and Chiozzi, P.: Types of crust beneath the Ligurian Sea, Terra Nova, 6(3), 255-266, https://doi.org/10.1111/j.1365-3121.1994.tb00493.x, 1994.

Pérez-Gussinyé, M. and Reston, T. J.: Rheological evolution during extension at nonvolcanic rifted margins: Onset of serpentinization and development of detachments leading to continental breakup, Journal of Geophysical Research: Solid Earth, 106(B3), 3961-3975, https://doi.org/10.1029/2000JB900325, 2001.

435 Prada, M., Ranero, C. R., Sallarès, V., Zitellini, N. and Grevemeyer, I.: Mantle exhumation and sequence of magmatic events in the Magnaghi-Vavilov Basin (Central Tyrrhenian, Italy): New constraints from geological and geophysical observations, Tectonophysics, 689, 133-142, https://doi.org/10.1016/j.tecto.2016.01.041, 2016.

Rehault, J.-P., Boillot, G. and Mauffret, A.: The Western Mediterranean Basin geological evolution, Marine Geology, 55(3), 447-477, https://doi.org/10.1016/0025-3227(84)90081-1, 1984.

440 Rollet, N., Déverchère, J., Beslier, M.-O., Guennoc, P., Réhault, J.-P., Sosson, M. and Truffert, C.: Back arc extension, tectonic inheritance, and volcanism in the Ligurian Sea, Western Mediterranean: LIGURIAN SEA BACK ARC STRUCTURE AND EVOLUTION, Tectonics, 21(3), 6-1-6-23, https://doi.org/10.1029/2001TC900027, 2002.

Rosenbaum, G., Lister, G. and Duboz, C.: Reconstruction of the tectonic evolution of the Western Mediterranean since the Oligocene, Journal of the Virtual Explorer, 8, 107-130, https://doi.org/10.3809/jvirtex.2002.00053, 2002.

445 Rüpke, L. H., Schmid, D. W., Perez-Gussinye, M. and Hartz, E.: Interrelation between rifting, faulting, sedimentation, and mantle serpentinization during continental margin formation-including examples from the Norwegian Sea: RIFTING, SEDIMENTATION, SERPENTINIZATION, Geochem. Geophys. Geosyst., 14(10), 4351-4369, https://doi.org/10.1002/ggge.20268, 2013.

Ryan, W. B. F., Carbotte, S. M., Coplan, J. O., O’Hara, S., Melkonian, A., Arko, R., Weissel, R. A., Ferrini, V., Goodwillie, 450 A., Nitsche, F., Bonczkowski, J. and Zemsky, R.: Global Multi-Resolution Topography synthesis, Geochemistry, Geophysics, Geosystems, 10(3), https://doi.org/10.1029/2008GC002332, 2009.

Sandiford, M.: Mechanics of basin inversion, Tectonophysics, 305(1), 109-120, https://doi.org/10.1016/S00401951(99)00023-2, 1999.

Schettino, A. and Turco, E.: Plate kinematics of the Western Mediterranean region during the Oligocene and Early Miocene, 455 Geophysical Journal International, 166(3), 1398-1423, https://doi.org/10.1111/j.1365-246X.2006.02997.x, 2006.

Snoke, J. A.: 85.12 FOCMEC: FOCal MEChanism determinations, in International Geophysics, vol. 81, pp. 1629-1630, Elsevier, https://doi.org/10.1016/S0074-6142(03)80291-7, , 2003.

Speranza, F., Villa, I. M., Sagnotti, L., Florindo, F., Cosentino, D., Cipollari, P. and Mattei, M.: Age of the Corsica-Sardinia rotation and Liguro-Provençal Basin spreading: new paleomagnetic and Ar/Ar evidence, Tectonophysics, 347(4), 231-251, https://doi.org/10.1016/S0040-1951(02)00031-8, 2002. 
https://doi.org/10.5194/se-2021-9

Preprint. Discussion started: 5 February 2021

(c) Author(s) 2021. CC BY 4.0 License.

(c) (1)

Storchak, D. A., Harris, J., Brown, L., Lieser, K., Shumba, B., Verney, R., Di Giacomo, D. and Korger, E. I. M.: Rebuild of the Bulletin of the International Seismological Centre (ISC), part 1: 1964-1979, Geoscience Letters, 4(1), 32, https://doi.org/10.1186/s40562-017-0098-z, 2017.

Waldhauser, F. and Ellsworth, W. L.: A Double-Difference Earthquake Location Algorithm: Method and Application to the 465 Northern Hayward Fault, California, Bulletin of the Seismological Society of America, 90(6), 1353-1368, https://doi.org/10.1785/0120000006, 2000.

Wessel, P., Luis, J. F., Uieda, L., Scharroo, R., Wobbe, F., Smith, W. H. F. and Tian, D.: The Generic Mapping Tools Version 6, Geochem. Geophys. Geosyst., 2019GC008515, https://doi.org/10.1029/2019GC008515, 2019.

Wiens, D. A. and Stein, S.: Age dependence of oceanic intraplate seismicity and implications for lithospheric evolution, Journal of Geophysical Research: Solid Earth, 88(B8), 6455-6468, https://doi.org/10.1029/JB088iB08p06455, 1983.

Zitellini, N., Ranero, C. R., Loreto, M. F., Ligi, M., Pastore, M., D’Oriano, F., Sallares, V., Grevemeyer, I., Moeller, S. and Prada, M.: Recent inversion of the Tyrrhenian Basin, Geology, 48(2), 123-127, https://doi.org/10.1130/G46774.1, 2020.

Zoback, M. L.: Stress field constraints on intraplate seismicity in eastern North America, Journal of Geophysical Research: Solid Earth, 97(B8), 11761-11782, https://doi.org/10.1029/92JB00221, 1992. 